\section{G. Slade Cargill III Receives 1994 Woody Award}

G. Slade Cargill III, a professor at Columbia University, received the 1994 Woody Award "in recognition of outstanding service and dedication on behalf of MRS as exemplified by Woody White, MRS President, 1984." John Bravman, 1994 MRS president, presented Cargill with the award during the 1994 MRS Fall Meeting council dinner.

Along with his official roles as a symposium co-chair during the 1985 MRS Meeting, and Fall Meeting Chair and MRS Councillor in 1988, Cargill served as MRS president in 1992. He contributed significantly to the interests of MRS by advancing the societal position of materials research and by revamping the finances used for running MRS meetings.

During his presidential tenure, Cargill co-authored a statement in support of the Advanced Materials and Processing Program (AMPP) in 1992. This statement was presented to chief Congress members and to presidents of other professional organizations concerned with materials science and engineering, advocating support for federal funding of the AMPP initiative.

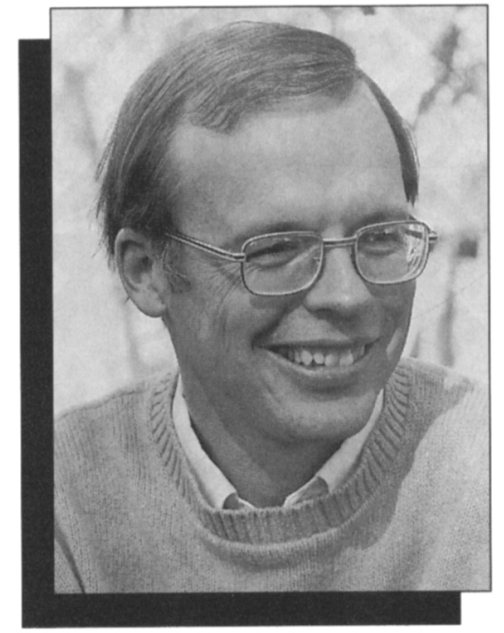

G. Slade Cargill III

Furthermore, addressing the Panel on the Nation's Research Universities of the President's Council of Advisors on Science and Technology, Cargill urged additional emphasis on interdisciplinary research, university/industry/government partnerships, and increased Federal support. Along with Jim Roberto (the then MRS past-president) and Tom Picraux (MRS president-elect), Cargill submitted a statement to the Special Commission on the Future of the National Science Foundation (NSF), asserting the key role that university research and graduate education in science and engineering plays in the U.S. economy and industrial competitiveness. The statement urged that NSF continue its support of these research and educational efforts.

As chair of the task force on costs associated with running MRS meetings, Cargill helped turn around MRS finances, improving planning, cost controls, and pricing. The task force set up the formulae for estimating costs and establishing registration fees.

Cargill cortinues serving on the JMR Advisory Review Board. His current research involves developing and applying $x$-ray scattering, $x$-ray absorption spectroscopy, and cathodoluminescence techniques to study structural defects, strain distributions, crack propagation, and electromigration, particularly in solid state devices and packaging structures.

\title{
MRS Homepage Under Construction on World Wide Web
}

Members can now obtain current information about upcoming MRS meetings, member services, and publications via the new MRS Homepage on the World Wide Web of the Internet.

The MRS Homepage, which went online at the beginning of January, contains a calendar of upcoming MRS meetings, with symposia and organizers identified for the 1995 Spring and Fall Meetings. Basic membership information is available-such as current benefits and services and instructions on how to form an MRS University Chapter or Section. Other topics include MRS Awards, Short Courses, Corporate Participation programs, and Publications.

A directory of current MRS officers and staff is provided, as is a downloadable electronic form for use in requesting further information.

The address of the MRS Homepage is http://dns.mrs.org/. To view it, users need to have a World Wide Web client installed on their computers or at their sites.

The MRS Homepage is still under construction, and further information will be announced in future issues of the MRS Bulletin. Among the services planned is an archive site for uploading and downloading research results and education$\mathrm{al} /$ research software.

Members and others are invited to provide suggestions and comments, $\mathrm{c} / \mathrm{o}$ Director of Membership Affairs, MRS, 9800 McKnight Rd, Pittsburgh, PA 15237; Phone 412/367-3004 x401; Fax 412/3674373; or E-mail: INFO@mrs.org. MाR]

\section{DO YOU HAVE QUESTIONS ABOUT THE 1995 MRS SPRING MEETING?}

\section{The Program is now available on the new MRS Homepage!}

World Wide Web address: hitp://dns.mrs.org/ MIRS 


\section{TECHNICAL PROGRAM}

A: Amorphous Silicon Technology - 1995

B: Defect and Impurity Engineered Semiconductors and Devices

C: Strained Layer Epitaxy - Materials, Processing, and Device Applications

D: Materials - Fabrication and Patterning at the Nanoscale

E: Visible Light-Emitting Materials and Devices

F: Low-Dielectric Constant Materials Synthesis and Applications in Microelectronics

G: Structure and Properties of Multilayered Thin Films

H: Fullerenes, Fullerene-Polymer Composites, Carbon Nanotubes and Their Applications

I: Mechanical Behavior of Diamond and Other Forms of Carbon

J: Hard Coatings for Plastic Substrates Materials, Processes, and Properties

K: High-Temperature Superconductors - Material and Fabrication Issues for Applications

L: Magnetic Ultrathin Films, Multilayers, and Surfaces

M: Electromechanical Phenomena in Complex Fluids

N: Polymer/Inorganic Interfaces

O: Ultraclean Semiconductor Processing Technology and Surface Chemical Cleaning and Passivation

P: Rapid Thermal and Integrated Processing IV

Q: Film Synthesis and Growth Using Energetic Beams

R: Modeling and Simulation of Thin-Film Processing

S: Electronic Packaging Materials Science VIII

T: Materials Reliability in Microelectronics V

U: Thin Films for Integrated Optics Applications

V: Flat Panel Display Materials

W: Materials for Electrochemical Energy Storage and Conversion - Batteries, Capacitors, and Fuel Cells

X: Frontiers of Materials Research

Y: Materials for Environmental Protection The Control of Air Quality

Z: Polymers in Medicine and Pharmacy

AA: Materials in Sports and Recreational Activities

\section{SHORT COURSE PROGRAM}

The Materials Research Society is offering its outstanding Short Course and Tutorial Program at the

1995 Spring Meeting. Up-to-date courses on the latest advances in the materials sciences and engineering complement the Spring Meeting symposium topics. Designed with something for everyone in research, development or processing of materials, the courses include overview presentations, indepth instruction in specialty and emerging areas, and practical discussions for problem solving, all taught by instructors who are experts in their fields. Class sizes are limited. Early preregistration is encouraged.

\section{EXHIBIT}

An MRS exhibit at the 1995 Spring Meeting will be located convenient to the technical session rooms. Features include the latest analytical and processing equipment, and publications, which closely parallel the nature of the technical symposia. For information, contact Mary E. Kaufold, Manager, Advertising and Exhibits, Materials Research Society, 9800

McKnight Road, Pittsburgh, PA 15237-6006;

Telephone (412) 367-3036, Fax (412) 367-4373.

\section{PROCEEDINGS}

Many symposia from this meeting will publish proceedings. MRS members and meeting attendees may purchase copies of these proceedings at special prepublication prices and receive priority shipment upon publication. Prices will be higher following the meeting. To take advantage of these special prices, order your proceedings while registering for the meeting. For information on nonmember proceedings prices and ordering procedures, contact the MRS Publications Department.

\section{SYMPOSIUM AIDE OPPORTUNITIES}

Graduate students who plan to attend the 1995 Spring Meeting in San Francisco and are willing to assist in the symposium presentations by operating audio-visual equipment are encouraged to apply for a Symposium Aide position. MRS will pay the 1995 Spring Meeting student registration fee (which includes complimentary student membership from July 1, 1995, through June 30, 1996) and a small stipend toward expenses, for symposium aides who work a minimum of four full half-day sessions. To request an application form and/or information, please contact Jane Stokes at MRS Headquarters, (412) 367-3004, X- 302, Fax (412) 367-4373.

\section{JOB PLACEMENT BULLETIN BOARD}

A Job Placement bulletin board for MRS meeting and short course attendees will be open Tuesday through Thursday during the 1995 Spring Meeting adjacent to the Exhibit.

For general meeting information or to request a Call for Papers booklet, a detailed 1995 Spring Meeting program, or information on short courses, publications, exhibit, job placement, or symposium aides, contact: 


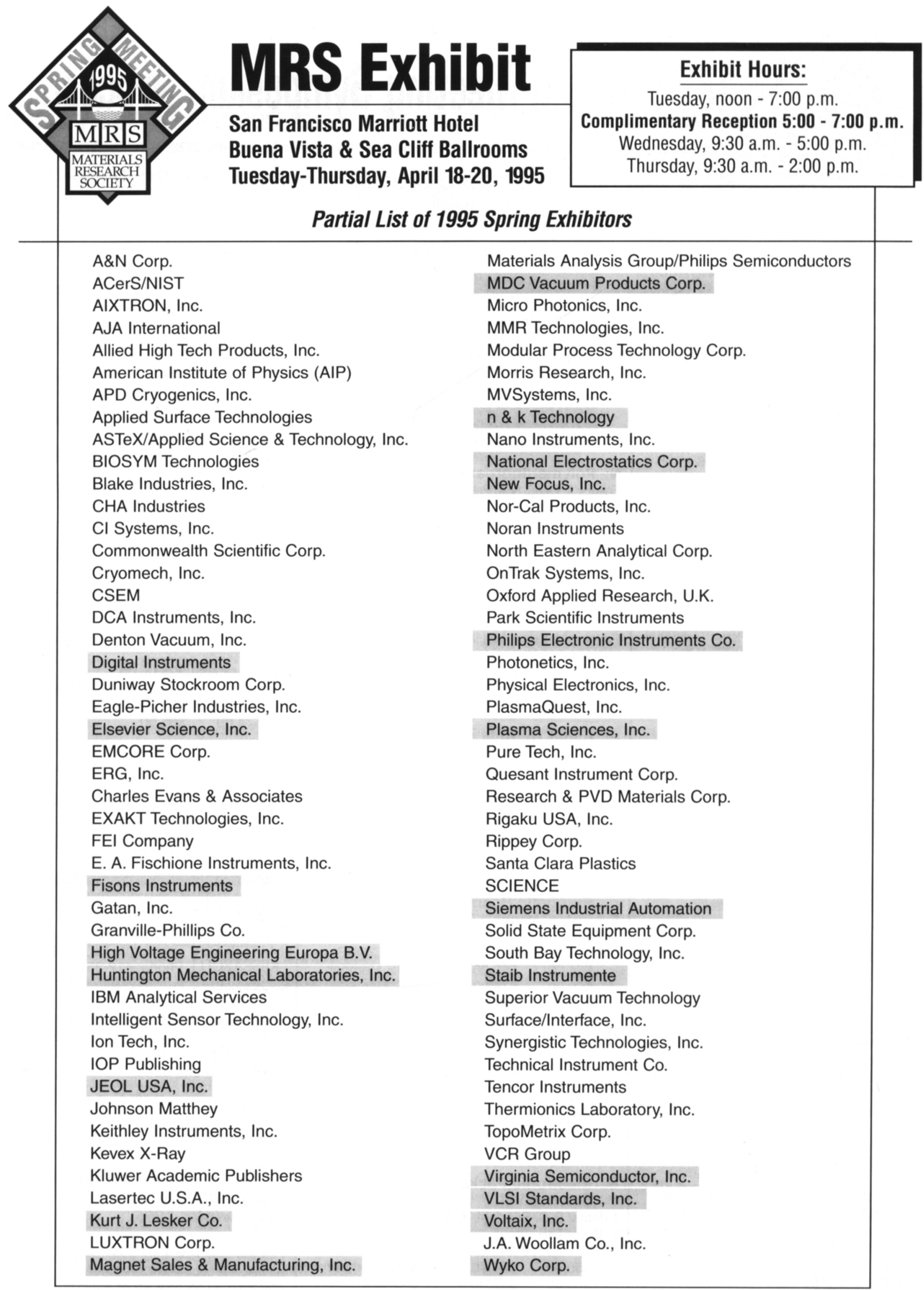




\section{Forthcoming from MRS at special pre-meeting prices... 19955 Spring Meeting Symposium Proceedings}

Place your order today for proceedings of the 1995 MRS Spring Meeting in San Francisco and SAVE!

Special pre-meeting prices effective until May 5, 1995. (After that, pay the higher price on the right.)

A: Amorphous Silicon Technology-1995 Editors: M. Hack, E.A. Schiff, M. Powell,

A. Matsuda, A. Madan

ISBN: $1-55899-280-4$

$\begin{array}{lll}\$ 53.00 & \$ 66.00 & \text { MRS Member } \\ \$ 66.00 & \$ 75.00 & \text { U.S. List } \\ \$ 75.00 & \$ 85.00 & \text { Foreign }\end{array}$

B: Defect- and Impurity-Engineered Semiconductors and Devices

Editors: S. Ashok, J. Chevallier, I. Akasaki, N.M. Johnson, B.L. Sopori

ISBN: 1-55899-281-2 $\$ 58.00 \quad \$ 72.00$

$\$ 72.00 \$ 83.00$

Code: $378-B$

$\$ 83.00$

$\$ 95.00$

MRS Membe

U.S. List

Foreign

C: Strained Layer Epitaxy-Materials, Processing, and Device Applications Editors: J. Bean, E. Fitzgerald, J. Hoyt, K-Y. Cheng

ISBN: 1-55899-282-0

$\$ 48.00 \quad \$ 62.00$

$\$ 62.00 \$ \$ 71.00$

Code: $379-B$

$\$ 71.00 \quad \$ 81.00$

MRS Member

U.S. List

Foreign

D: Materials-Fabrication and Patterning at the Nanoscale

Editors: C.R.K. Marrian, K. Kash, F. Cerrina,

M. Lagally

ISBN: 1-55899-283-9

$\$ 58.00 \quad \$ 72.00$

$\$ 72.00 \quad \$ 83.00$

Code: $380-\mathrm{B}$

$\$ 83.00 \quad \$ 95.00$

MRS Member

U.S. List

Foreign

F: Low-Dielectric Constant MaterialsSynthesis and Applications in Microelectronics

Editors: T-M. Lu, S.P. Murarka, T.S. Kuan, C.H. Ting

ISBN: 1-55899-284-7

$\$ 58.00 \quad \$ 72.00$

$\$ 72.00 \quad \$ 83.00$

Code: $381-\mathrm{B}$

MRS Member

$\$ 83.00 \quad \$ 95.00$

U.S. List

Foreign

G: Structure and Properties of Multilayered Thin Films

Editors: T.D. Nguyen, B.M. Lairson, B.M. Clemens, K. Sato, S-C. Shin

ISBN: 1-55899-285-5

$\$ 59.00 \quad \$ 74.00$

Code: 382-B

$\$ 74.00 \quad \$ 85.00$

MRS Member

$\$ 85.00$

$\$ 98.00$

U.S. List

Foreign

I: Mechanical Behavior of Diamond and Other Forms of Carbon

Editors: M.D. Drory, M.S. Donley, D. Bogy, J.E. Field

ISBN: 1-55899-286-3

$\$ 54.00 \quad \$ 67.00$

$\$ 67.00 \quad \$ 77.00$

$\$ 77.00 \quad \$ 89.00$

Code: 383-B

MRS Member

U.S. List

Foreign
L: Magnetic Ultrathin Films, Multilayers and Surfaces

Editors: A. Fert, H. Fujimori, G. Guntherodt,

B. Heinrich, W.F. Egelhoff, Jr., E.E. Marinero,

R.L. White

ISBN: 1-55899-287-1

$\begin{array}{lll}\$ 54.00 & \$ 68.00 & \text { MRS Member } \\ \$ 68.00 & \$ 78.00 & \text { U.S. List } \\ \$ 78.00 & \$ 90.00 & \text { Foreign }\end{array}$

N: Polymer/Inorganic Interfaces II

Editors: L. Drzal, N.A. Peppas, R.L. Opila, C. Schutte

ISBN: 1-55899-288-X Code: 385-B

$\$ 52.00 \$ 64.00 \quad$ MRS Member

$\$ 64.00 \quad \$ 74.00$

U.S. List

$\$ 74.00 \quad \$ 85.00$

Foreign

O: Ultraclean Semiconductor Processing Technology and Surface Chemical Cleaning and Passivation

Editors: M. Liehr, M. Hirose, M. Heyns, H. Parks

ISBN: 1-55899-289-8 Code: 386-B

$\$ 48.00 \$ 57.00 \quad$ MRS Member

$\$ 57.00 \quad \$ 63.00 \quad$ U.S. List

$\$ 63.00 \$ 72.00 \quad$ Foreign

P: Rapid Thermal and Integrated Processing IV

Editors: J.C. Sturm, J.C. Gelpey, S.R.J. Brueck, A. Kermani, J.L. Regolini

ISBN: 1-55899-290-1 $\$ 49.00 \quad \$ 57.00$

$\$ 57.00 \quad \$ 63.00$

Code: $387-B$

$\$ 63.00$

$\$ 72.00$

MRS Member

U.S. List

Foreign

Q: Film Synthesis and Growth Using Energetic Beams

Editors: H.A. Atwater, J.T. Dickinson, D.H. Lowndes, A. Polman

ISBN: 1-55899-291-X $\$ 54.00 \quad \$ 68.00$

$\$ 68.00 \quad \$ 78.00$

$\$ 78.00 \quad \$ 89.00$

Code: 388-B

MRS Member

U.S. List

Foreign

R: Modeling and Simulation of Thin-Film Processing

Editors: C.A. Volkert, R.J. Kee, D.J. Srolovitz, M.J. Fluss

ISBN: 1-55899-292-8

$\$ 52.00 \quad \$ 66.00$

$\$ 66.00 \quad \$ 77.00$

Code: $389-\mathrm{B}$

$\$ 77.00$

$\$ 88.00$

MRS Member

U.S. List

Foreign

S: Electronic Packaging Materials Science VIII

Editors: R.C. Sundahl, K.A. Jackson, K-N. Tu,

P. Børgesen

ISBN: 1-55899-293-6

$\$ 50.00 \$ \$ 63.00$

$\$ 63.00 \quad \$ 72.00$

$\$ 72.00 \quad \$ 83.00$
Code: $390-\mathrm{B}$ MRS Member

U.S. List

Foreign
T: Materials Reliability in Microelectronics $V$

Editors: A.S. Oates, K. Gadepally, R. Rosenberg, W.F. Filter, L. Greer

ISBN: 1-55899-294-4

$\$ 52.00 \quad \$ 64.00$

$\$ 64.00 \quad \$ 74.00$

$\$ 74.00 \quad \$ 85.00$

Code: 391-B MRS Member

U.S. List

Foreign

U: Thin Films for Integrated Optics Applications

Editors: B.W.Wessels, D.M. Walba

ISBN: 1-55899-295-2 Code: 392-B

$\$ 52.00 \quad \$ 64.00 \quad$ MRS Member

$\$ 64.00 \quad \$ 74.00 \quad$ U.S. List

$\$ 74.00 \quad \$ 85.00 \quad$ Foreign

W: Materials for Electrochemical Energy Storage and Conversion-

Batteries, Capacitors and Fuel Cells

Editors: D.H. Doughty, B. Vyas, J.R. Huff,

T. Takamura

ISBN: 1-55899-296-0 Code: 393-B

$\$ 52.00 \quad \$ 64.00 \quad$ MRS Member

$\$ 64.00 \quad \$ 74.00 \quad$ U.S. List

$\$ 74.00 \quad \$ 85.00 \quad$ Foreign

Z: Polymers in Medicine and Pharmacy Editors: A.G. Mikos, K.W. Leong, M.L. Radomsky, J.A. Tamada, M.J. Yaszemski

ISBN: 1-55899-297-9

$\$ 54.00 \quad \$ 68.00$

Code: 394-B

$\$ 68.00 \quad \$ 78.00$

MRS Member

$\$ 78.00$

$\$ 89.00$

Foreign

\section{MRS Materials Research Society \\ MATERIALS Pittsburgh, PA 15237 \\ Phone: 412-367-3012 \\ Fax: $412-367-4373$}

In Europe, Africa and the Middle East:

Clarke Associates-Europe, Ltd.

Fourth Floor, The Rackhay

Queen Charlotte Street

Bristol BS1 4HJ

ENGLAND

Phone: 0272268864

Fax: 0272226437

\section{These books are scheduled for publication by fall or early winter 1995.}

Free shipping (UPS/surface only) on all prepaid orders Air freight is additional. Standard shipping and handling charges of $\$ 3$ per book will be added to each order that is not prepaid. Contact MRS for special shipping options 